\title{
RIVER ARCHAEOLOGY - A NEW TOOL FOR HISTORICAL HYDROLOGY
}

\author{
Attila J. Tóth \\ National Office of Cultural Heritage \\ Budapest, Hungary \\ attila.toth@koh.hu
}

\begin{abstract}
River archaeology is consisting of underwater research of the rivers themselves, and also the archaeology of the valleys/floodplains with special interest in humanenvironmental interactions (reconstructing space, environment, economy and society on the basis of the material culture and traces of human impacts). As historical hydrology is occupying similar questions from the hydrologist's point of view, the combination of different approaches offers fruitful cooperation for both disciplines. The paper presents the type, nature and problems of archaeological record through recent work in the Drava river basin.
\end{abstract}

Keywords: river archaeology, historical hydrology, underwater survey, GIS, Drava river.

\section{INTRODUCTION}

River archaeology is a new field of research (Bonnamour, 2000; Dumont, 2006; Tóth, 2006a) consisting of underwater research of the rivers themselves, and also the archaeology of the valleys/floodplains with special interest in human-environmental interactions (reconstructing space, environment, economy and society on the basis of the material culture and traces of human impacts). As historical hydrology is occupying similar questions from the hydrologist's point of view (Brázdil and Kundzewicz, 2006) the combination of different approaches offers fruitful cooperation for both disciplines. Geology (geomorphology, sedimentology, geophysics), dendrochronology etc. should be taken into consideration as partner discipline (Brown, 1997; Howard and Macklin, 1999; Hudson-Edwards et al., 1999; Tímár Sümegi - Horváth, 2005; Tóth et al.,1997; Grynaeus, 2003).

\section{NATURE OF DATA AND TIME PERSPECTIVE}

Due to the extreme floods around the turn of the millennium the study of paleofloods dominates research themes (Benito, 2002; Brázdil and Kundzewicz, 2006; Glaser and Stangl, 2003). Hystorical hydrology uses accurate instrumental observations from $19^{\text {th }}-20^{\text {th }} \mathrm{c}$., and also pre-instrumental written sources of variable nature and accuracy. Extreme floods have been registered since antiquity, but continuous, more accurate records start from the Renaissance period $\left(15^{\text {th }} \mathrm{c}\right.$.).

Underwater archaeological researches and topographical survey of river valley offer a wider perspective: the last 8.000-10.000 years - since the beginning of agriculture and intensification of human impact upon nature. Archaeological record could be divided into direct and indirect information. The first group consists of traces of floods 
(as sterile river sediment layer over archaeological features) or erosion. The Governor's Palace of the Pannonia Inferior has been discovered in the mid- $19^{\text {th }} \mathrm{c}$. on an island (Hajógyári-sziget) at Budapest, Hungary. The complex was built for the first governor of the province (Hadrian, the later emperor) in the early $2^{\text {nd }}$ C. A.D. The building was abandoned sometime around the $2^{\text {nd }}$ half of the $3^{\text {rd }}$ C. A.D., and it was related to the rising of the Danube water level (Kérdő, 1996). The Roman limes, the river frontier, which consisted of a system of watch towers, fortifications, camps, and bridge heads, was also influenced by the Danube. A bridge head at Bölcske (Tolna County, South Hungary) once at the right bank of the river has been found in the middle of the river as the result of the movement of the channel towards the west since the $4^{\text {th }}$ C. A.D. (Soproni, 1990) Bridges, ships, ports, fords and remains of fisheries are also direct evidences for the nature and use of the rivers.

Indirect information derives from topographical survey: the geographical position of settlements and changes of settlement patterns reflect river environment, the average level of floods, and changes of river channels (which functioned as trade routes, boundaries, sources of energy and water etc.).

\section{UNDERWATER ARCHAEOLOGY AND RIVER ARCHAEOLOGY}

Underwater archaeology is a synonym for maritime archaeology not only for the public, but even for many archaeologists. This situation is due to the hostile river environment. Strong current, low visibility makes diving dangerous, survey and documentation a time consuming activity. Searching, photographing in the "Great Blue" is much more spectacular than it is in the "Great Brown", and easier to get sponsors to it. It is largely forgotten, that unlike marine environment organic material is conserved much better in freshwater (rivers and lakes).

The archaeological mapping is the urgent task of Hungarian archaeology. Although ca. 55.000 sites are known from the country we estimate another 15.000-20.000 sites waiting for discovery. In the case of underwater sites and others on the riverbank (covered by dense forest or bush) are even worse: probably $90-95 \%$ of the underwater sites has not been discovered yet! Naturally only the known sites could be studied and protected. The National Office of Cultural Heritage of Hungary has started a topographical project in the Drava river valley (South Hungary). Dozens of new sites have been identified on the high bank and on the floodplain dating from Prehistoric period to early-modern times, including earth-fortifications and an outstanding logboat "cemetery" in 2005 (Tóth, 2006b and 2007).

\subsection{The Drávatamási logboat site and its environmental context}

Drávatamási is a small village on the North bank of the Drava in Southwest Hungary (Somogy County). The river is approximately $100 \mathrm{~m}$ wide, the average depth is between 4-7 m, the current is strong, and the visibility is good (up to $1 \mathrm{~m}$, sometimes even better). First investigation was carried out by the Dráva Museum of Barcs in 1992, when the low water level made it possible to photograph some dugouts. An Ottoman period (17th c.) copper jug was also collected from a ship. Based on these discoveries we have organised an international expedition including Austrian, Croatian, French and Hungarian archaeologists and divers.

Between 2005 and 2007 three surveys were organised by the National Office of Cultural Heritage and the Hungarian Archaeological and Art-historian Society. 30 
dugouts have been found in very good condition in a limited area of the river. This is the largest logboat cemetery in Europe, and one of the largest in the World! The ships were carved out from a single piece of oak. They are very big (10-13 m long, $1,2-1,5 \mathrm{~m}$ wide) and all have the same characteristics: round cross section, lack of inner reinforcement. Close to these finds we also found pieces of Ottoman period ceramics and some earlier, 11th-13th c. ceramics (dating to the so-called Arpadianperiod). We concluded that the site extends to both the Croatian and the Hungarian side of the river. One of the monoxyls has been documented in detail by the French team. We have also collected wooden samples for dendrochronology. One of the great surprises of this survey was the discovery of an almost intact copper cauldron, which could be dated to the Ottoman-period like the mentioned jug. The cauldron has been found in the immediate vicinity of two of our logboats.

All of the boats has a pointed, flat bow. The aft however is straight and open. A notch with treenails is visible in this part which suggests that a wooden plank has been fixed there to close the aft. There are oval or circular hoes along the edges of the side-wall, probably holding some attachments. A hexagonal axis of a watermill wheel was also found and two large timbers with holes for attachment. The morphological homogeneity and the traces of attachment suggest that the monoxyls were not individual objects and accumulated there occasionally, but were part of a larger structure. Although dendrochronology did not give a precise date due to the lack of "master chronology" for the Drava basin, it still shows that all the trees has been cut during the same period.

The last, 2007 campaign surprised us with new discoveries. We have also found a millstone under one of our logboats. The most exciting finds were two planks found some meters upstream of logboat 20 . There are hand made iron nails and iron sintles on the planks, which attest that they derive from a plank-built wreck probably covered by the sand dune. The method of the use of the iron nails is quiet rare: they connect the planks together similarly to the ancient "shell first" concept. There are only a few traces for the nails connecting the planks with the timbers. The only parallel is known from Altenwörth, in the Austrian Danube. That ship is dated to early 19th c. The elongated oval plate of the sintles is identical with the figures of a catalogue of ironworks published in Gräz (Austria) in 1825. The Austrian catalogue name this kind of sintles "Turkish-sintles". The main purpose of the 2008 research is to excavate and document this strange wreck.

The question of interpretation has brought paleo-environmental problems into the focus. The study of $18^{\text {th }}-19^{\text {th }} \mathrm{c}$. maps, historical texts and the observations mentioned above give way to two hypotheses. The first one is the water mill hypothesis. It is based on the watermill axis, the millstone found at the site, and ethnographic descriptions mentioning floating mills planted on ships and logboats used abundantly on the Drava. An $18^{\text {th }} \mathrm{c}$. map shows a group of such mills just $1 \mathrm{~km}$ upstream of our site. Ottoman period sources mention a number of ship-mills in the environment of Barcs (nearest town to Drávatamási). This hypothesis raises the question of site formation: 30 logboats (or more) represent a large number of floating mills, destructed in the same time at the same area. These mills were usually based at suitable places in groups, called mill-villages. The site could be such a village. A possible hypothesis for the destruction is a flood, which broke away the ropes of the mills. 
The second hypothesis is supported by G. Petthö (a $17^{\text {th }} \mathrm{c}$. historian), who described a Hungarian surprise attack against two small fortifications and a bridge at Drávatamási in 1603. The Ottoman period find material, a timber with rectangular holes (for attachment of the boats) and the absence of closing-planks at the aft of the boats (destructed?) could also support this hypothesis. There is a possible answer for the question of watermill elements: the Turks confiscated all floatable objects, including boats and mills on the conquested territory to build a military bridge.

Archive maps show that the river changed a lot since the $18^{\text {th }} \mathrm{c}$. mostly due to regularisation (cutting of meadners). Unfortunatelly we do not have accurate maps for the Ottoman period or the period before, but river environment should have changed since those times. We should interpret our site in its original context, which requires a wider, interdisciplinary perspective.

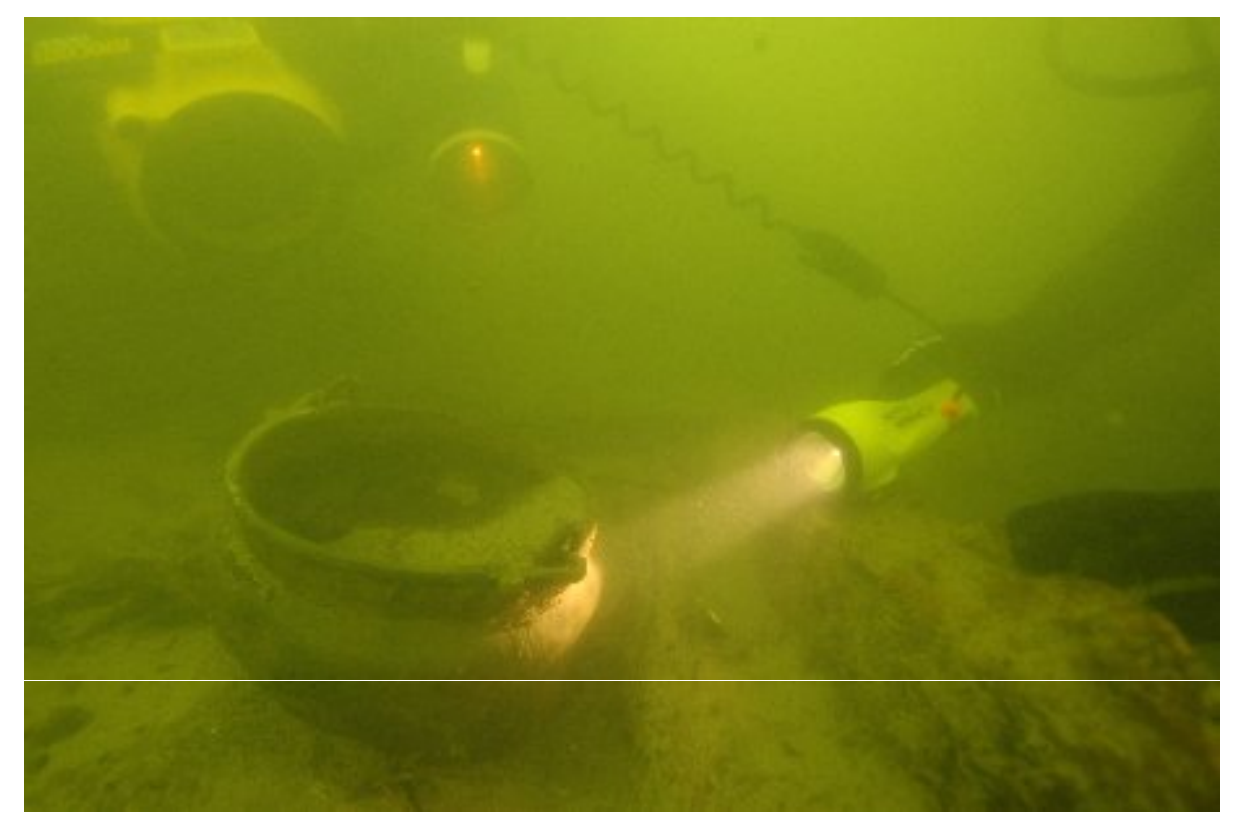

Figure 1. The copper cauldron in situ. Photo: K. Zubčič, Croatian Conservation Institute

\subsection{First river archaeological observations}

Parallel to underwater survey we organised short field survey East of Drávatamási and in a larger sample area on the high-bank of the Dráva West of Vízvár. Archaeological information from this border zone between former Yugoslavia and Hungary is scarce due to Cold War situation (the river and its banks were not accesible for scientists). These preliminary surveys resulted a large number of new sites from different periods. An abundant source of information has been collected from archive aerial photos. The Museum and Institute of Military History has a large collection of archive cartographical ortophotos from the 1950's to early 1980's. Series of photos from the Drava area has been scanned and some of them georeferred. A large number of meanders and river channels are visible (Figure 2.). A lot of them could be identified on $18^{\text {th }} \mathrm{c}$. maps, but some were not depicted, because they were already inactive and filled up at the time of mapping. 


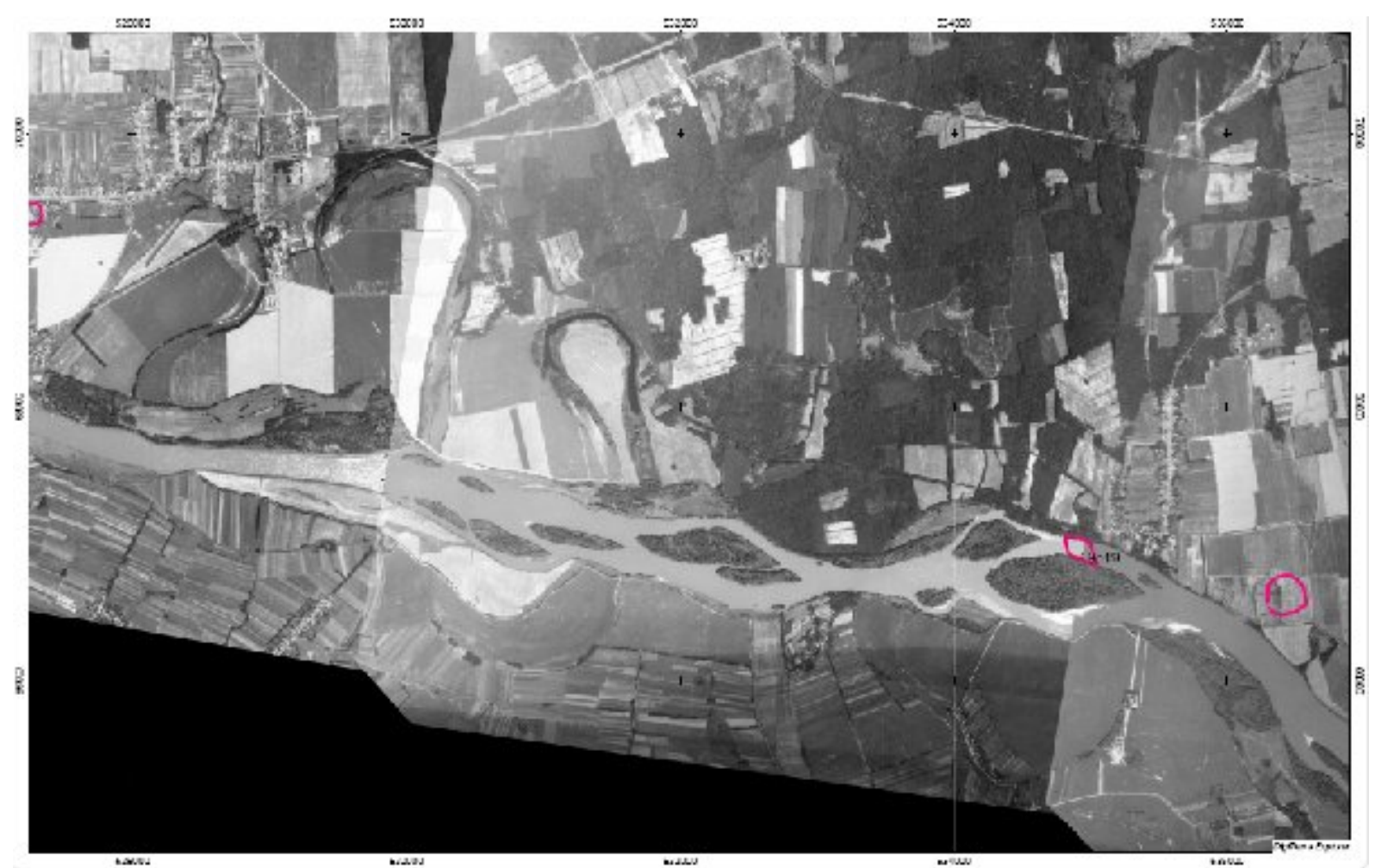

Figure 2. Mosaic of georefered aerial photos of the Dráva valley, near the logboat site. Archaeological sites marked with pink. Meanders (oxbow lakes) cut during the $19^{\text {th }}$ c. are clearly visible. By Péter Szöcs, National Office of Cultural Heritage

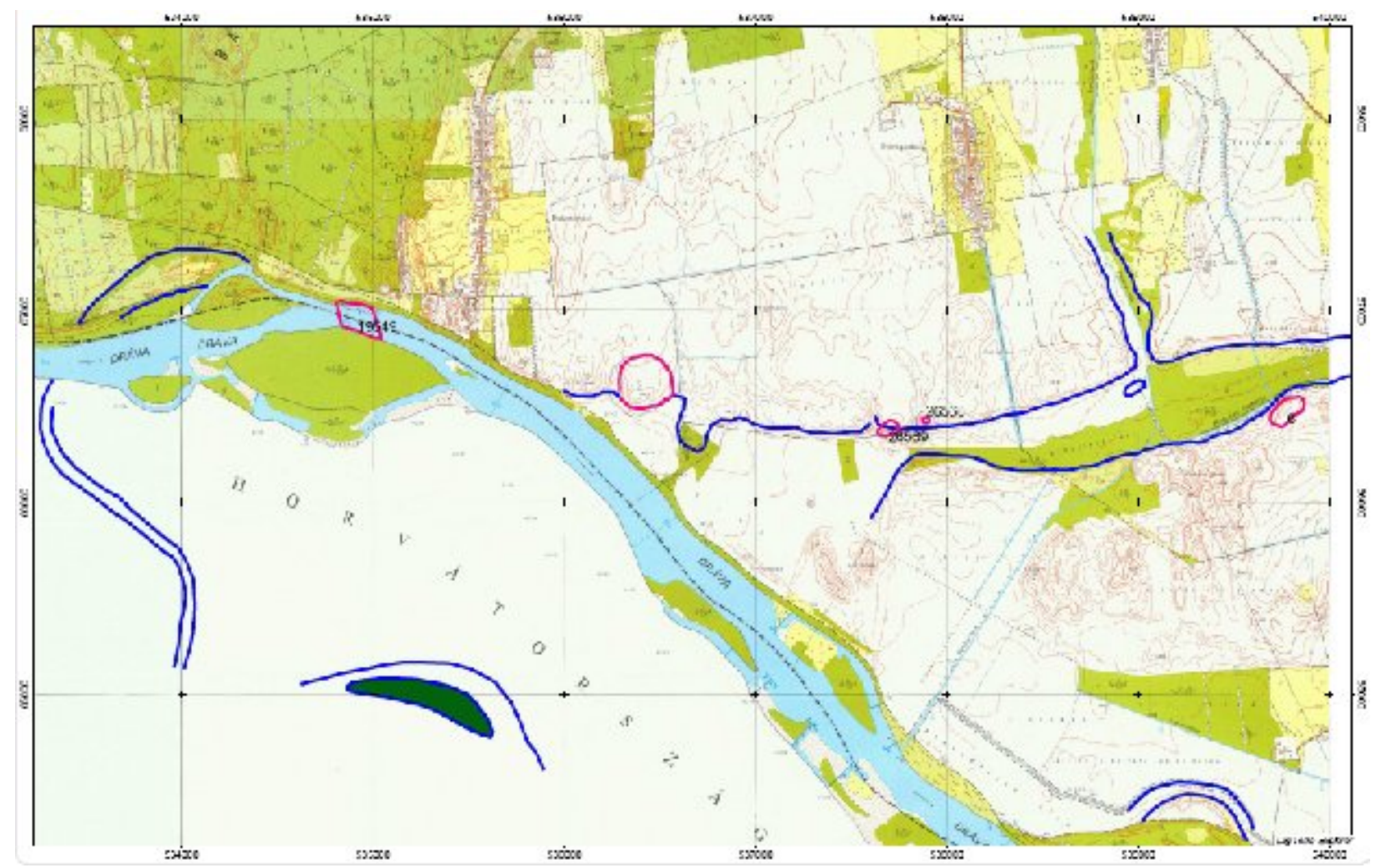

Fig. 3. Topographical map with the representation of paleo-channels (blue) and archaeological sites (pink) in the area of Drávatamási 
Combining archaeological observations and paleo-channel data resuled interesting paleo-hydro-environmental information. West of the logboat cemetery (id.no. 19519) an $\mathrm{S}$ shaped meander has been cut during $19^{\text {th }} \mathrm{c}$. regulations. Our site was however in the active riverbed at that time. A large East-West channel has been identified East of our site (Figure 3., blue). We documented archaeological sites both on its North and South banks (Figure 3., pink). It is evident that the ancient Drava was the main factor for human activity there. The creation, life and abandonment of these sites could be connected not only to historical events, but also to the life of the river. The earliest finds come from the Late Bronze Age. Roman and Medieval finds have been also collected. The latest feature is an Ottoman period small earth-fortification, a guard-post, which could controll the river. It could mean that there was a river channel from the Late Bronze Age to the Ottoman period (sometime during the $17^{\text {th }}$ c.), but this channel disappeared by the end of the $18^{\text {th }} \mathrm{c}$. The formation of the logboat site and the closing of the East-West channel occured (archaeologically) in the same time. Relation of the historical and the natural event requires futher research.

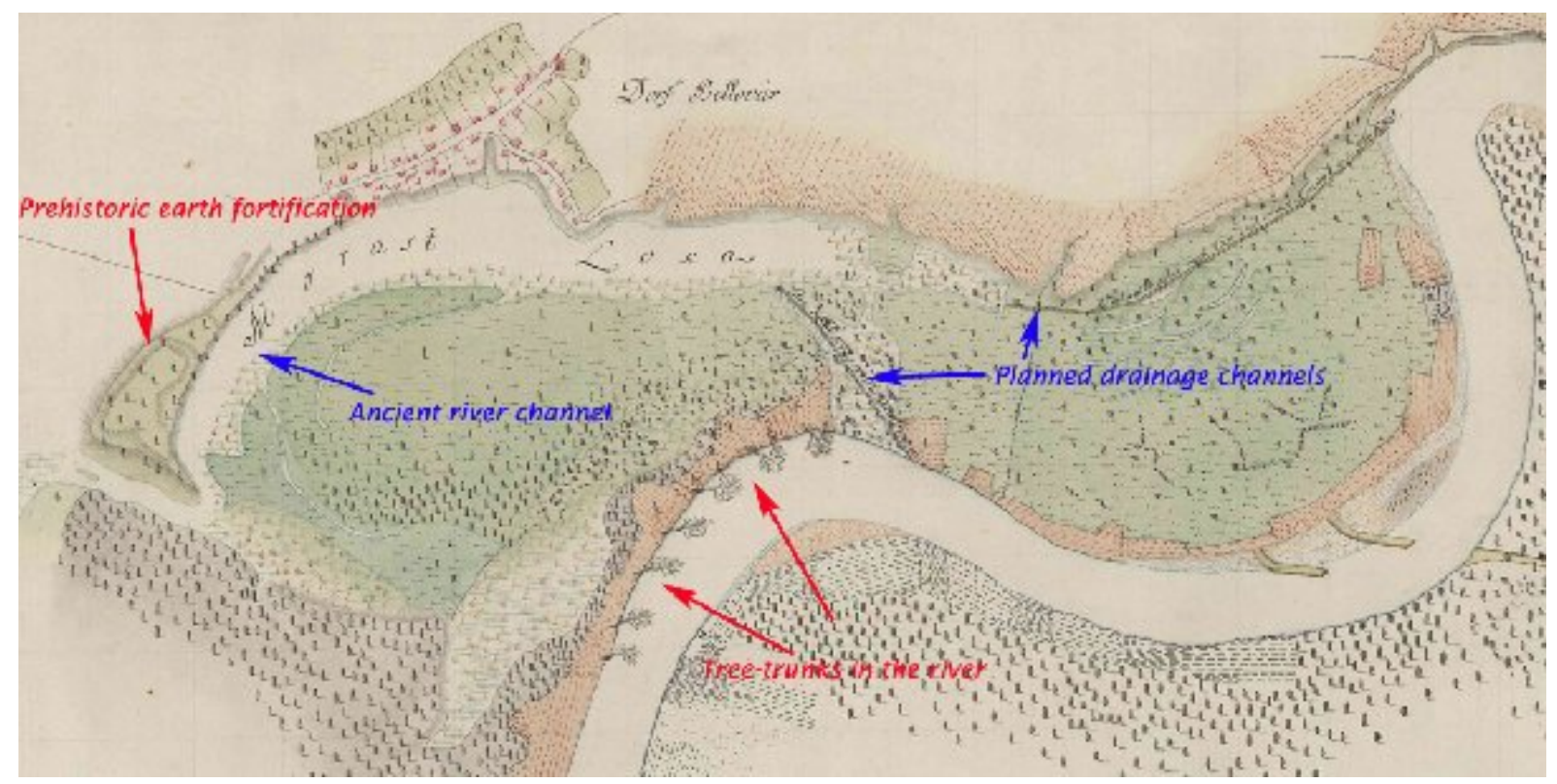

Fig. 4. Archaeological and hydro-environmental features at Bélavár (Somogy County). Detail of a manuscript map,1795. Collection of the National Széchenyi Library, Budapest

In the case of the sample area between Örtilos and Vízvár the survey shows us, that the fortifications and fortified centres were built on the high (loess) bank on the North edge of the floodplain. Natural loess "peninsulas" cut by paleo-channels were preferred for fortified sites. The river is in a reasonable distance from this high bank nowadays, but surface morphology, aerial photos and in some cases archive maps testifie former relationship between the Drava and these sites. In the case of the prehistoric fortified site (re-used in Ottoman period) at Bélavár the late $18^{\text {th }} \mathrm{c}$. map shows the last phase of transformation of this historical-hydrological situation. Large settlement sites were also found on the low floodplain in some cases, these date to the Árpádian-period $\left(11^{\text {th }}-13^{\text {th }}\right.$ c.) which suggest a low average flood level for a considerable period, or some kind of adaptation to this humid environment. 


\section{FURTHER QUESTIONS}

Although a number of historical, archaeological studies discussed special problems related to river environment, even in the case of the Danube Basin, complex, interdiscilinary studies are still awaiting. At this point it is enough to refer to the close relation between Early and Middle Neolithic sites and the Tisza river in the Great Hungarian Plain (Kosse, 1979) and studies concerning the history of navigation on the Danube (Neweklowsky, 1952-1954-1964) or the mentioned Drava (Leskoschek, 1972) based on depictions and written sources. Underwater archaeology came into the picture much later, but studies on some European rivers are accessible (Saône: Bonnamour, 2000; Charente: Dumont et al. 2003; Ljubljanica: Gaspari 2003). The idea and first example for combining underwater archaeology and natural sciences diffused from France (Dumont 2006) due to international cooperation programmes. The circle of research fields and disciplinas are broadening and the purpose of this paper is to inform hydrologists about this new field of research.

Proposed fields for cooperation:

- Paleochannel study (formation, evolution, characteristics).

- Question of driving forces: extreme, violent events (floods), and gradual changes.

- Traces of human impacts on river environment (e.g. built elements, like bridges, ports as part of the long-term artificial landscape in Roman Tiberis river: Graham, 2005).

- River and sediment types and strategies of archaeological cultures (e.g. Howard and Macklin, 1999; Hudson-Edwards et al. 1999).

- Islands as special places in culture and history (Roman and Medieval towns were often founded near river islands, and the life of these islands influenced the evolution of the settlements).

- Land use, changes in vegetation cover, and climat change and their influence on rivers and local communities.

- GIS combining interdisciplinary data.

\section{References}

Benito, G. (2003): Paleoflood hydrology in Europe. In: Thorndycraft et al. 2003, 1-24.

Bonnamour, L. (2000): Archéologie de la Saône. Paris

Brázdil, R., Kundzewicz, Z. W. (2006): Historical hydrology - Editorial. Hydrol. Sci. J., Vol. 51(5) ; 733738.

Brown, A. G. (1997): Alluvial geoarchaeology: floodplain archaeology and environmental change. Cambridge

Dumont, A., Marioti, J-F., Pichon, M. (2003): La Charente à Taillebourg-Port d'Envaux (France, dép. Charente-Maritime). Premiers résultats d'une prospection thématique subaquatique. Archäologisches Korrespondenzblatt Vol. 33 (4) ; 585-596.

Dumont, A. Ed. (2006): Archéologie des lacs et des cours d'eau. Paris

Gaspari, A. (2003): Archaeology of the Ljubljanica River (Slovenia): early underwater investigations and some current issues. International Journal of Nautical Archaeology Vol. 32 (1); 42-52

Glaser, R., Stangl, H. (2003): Floods in Central Europe since 1300. In: Thorndycraft et al. 2003, 93-98

Graham, S. (2005): Of lumberjacks and brick stamps: working with the Tiber as infrastructure. In:

MacMahon, A., Price, J. Eds.: Roman working and urban living. Oxford; 106-124.

Grynaeus, A. (2003): Dendrochronology and Environmental History. In: Laszlovszky, J. - Szabó, P. eds.: People and Nature. Budapest, 175-193. 
Howard, A. J., Macklin, M. G. (1999): A generic geomorphological approach to archaeological interpretation and prospection in British river valleys: a guide for archaeologists investigating Holocene landscapes. Antiquity, Vol. 73; 527-541.

Hudson-Edwards, K. A., Mark G. Macklin, M. G., Taylor, M. P. (1999): 2000 years of sediment-borne heavy metal storage in the Yorkshire Ouse basin, NE England, UK. Hydrol. Process, Vol. 13; 10871102.

H, Kérdő, K. (1997): Test excavations at the Aquincum Governor's Palace on the Óbuda Hajógyár Island. Aquincumi Füzetek Vol.3; 27-39.

Kosse,K. (1979): Settlement ecology of the Körös and Linear Pottery Cultures in Hungary. BAR IS 64, Oxford

Leskoschek, F. (1972): Schiffahrt und Flösserei auf der Drau. Zeitschrift des Historischen Vereines für Steiermark, Vol. 63; 115-152

Neweklowsky, E. (1952-1954-1964): Die Schiffart und Flösserei in Raume der oberen Donau. I-III. Linz

Newson, M. (1994): Hydrology and the river environment. Oxford

Soproni, S. (1989): Eine Spátrömische Festung im Donaubett bei Bölcske. III. Internationaler Kongress für archaologische Erforschung der Binnengewasser. Zürich, 1990.

Thorndycraft, V. R., Benito, V. G., Barriendos, M. and Llasat M. C. eds. (2003): Palaeofloods, Historical Floods and Climatic Variability: Applications in Flood Risk Assessment (Proceedings of the PHEFRA Workshop, Barcelona, 16-19th October, 2002).

Tímár, G., Sümegi, P., Horváth, F. (2005): Late Quarternary dynamics of the Tisza River: Evidence of climatic and tectonic controls. Tectophysics Vol. 410; 97-110.

Tóth, J. A. (2006a): River archaeology - a new field of research. New technologies in Archeology, International Symposium, Hungarian National Museum, 2005. Archeometriai Múhely, Vol. 2006/1; 6166. (http://www.ace.hu/am)

Tóth, J. A. (2006b): The Drávatamási Ship Project. International Logboat Conference, North Carolina Maritime Museum, Beaufort, NC, USA

Tóth, J. A. (2007): The HERMA and the Argonauts Programs: Practices and Problems of Heritage Mapping in River Environment (Hungary). Web Journal on Cultural Patrimony, Vol. 2/1; 97-102. (http://www.webjournal.unior.it)

Tóth, T., Vida, R., Horvath, F., Simpkin, P. (1997): Shallow-water single and multichannel seismic profiling in a riverine environment. The Leading Edge, Vol. 16; no. 11; 1691-1695. 